WIENER SLAVISTISCHES JAHRBUCH, Band 57/2011, 21-35

(C) 2011 by Österreichische Akademie der Wissenschaften, Wien

J I Ř Í H O L Ý

\title{
Der Exotismus und Apollinaires Spuren in Biebls S lodí jež dováži čaj a kávu und Nový Ikaros
}

1. Konstantin Biebl, der aus dem mittelböhmischen Slavětín in der Nähe von Louny stammte, fand den magischen Ort seiner Poesie im exotischen Orient und vor allem auf Java. Die indonesischen Inseln existierten nicht nur in seiner Vorstellung, sondern er lernte sie an der Jahreswende 1926/27 auf seiner berühmt gewordenen Reise nach Südostasien auch persönlich kennen. ${ }^{1}$ Ähnlich wie zum Beispiel Petr

${ }^{1}$ Anhand der Korrespondenz des Dichters können wir seine Reise, die von Oktober 1926 bis Februar 1927 dauerte, wenigstens annähernd rekonstruieren. Am 28. 10. 1926 schiffte sich Biebl im italienischen Genua auf der Yorck ein, mit der er über Port Said (Ausflug nach Kairo) und Ceylon (Sri Lanka) bis nach Singapur gelangte. Von Singapur reiste er mit dem Schiff Plancius nach Jakarta (Tanjunk Priok) weiter, wo er Ende November 1926 ankam. Am 3. 12. fuhr er mit dem Zug auf das Festland von Java nach Semarang, wo er einige Zeit beim tschechischen Arzt Dr. Kselík verbrachte, dem er in der Ordination aushalf (Biebl hatte - ohne Abschluss - Medizin studiert). Gemeinsam besuchten sie den berühmten Borobudur, den größten buddhistischen Tempel der Welt. Dann begab sich Biebl in den Osten Javas nach Surabay. Während seines Aufenthalts in Indonesien brach im Westen Javas ein Aufstand aus, Biebl wurde nach eigenem Zeugnis von der örtlichen niederländischen Polizei verhört; einigen Freunden gegenüber behauptete er, dass er mit den Aufständischen sympathisiert hatte und deswegen vorzeitig nach Europa zurückkehren musste. Jiř́ Sixta schreibt sogar: ,[...] pomáhal ošetřovat raněné, sbližoval se s domorodci, přemáhaje jejich plachost a nedůvěru [...]. Teror kolonialistů, deportace provinilců na Novou Guineu, to vše pobouřilo nakonec básníka k otevřenému protestu a bylo prŕíčinou, že jeho studijní cesta musela předčasně skončit.“ [... er half, Verwundete zu pflegen, er fand Zugang zu den Einheimischen, deren Schüchternheit und Misstrauen er überwand ... Der Terror der Kolonialisten, die Deportation der Schuldigen nach Neu Guinea, das alles empörte den Dichter letztlich bis zum offenen Protest und war Grund dafür, dass seine Studienreise vorzeitig enden musste] (Sixta 1962: 65-66). Unklar ist auch die Identität von Olga Trunečková, die ihn auf dieser Reise begleitete (,krásná společnice“, die schöne Begleiterin, im Gedicht $V$ Africe, In Afrika) und einige Briefe unterschrieb; angeblich ist sie in Indonesien geblieben. (Der Name Olga taucht auch in der Widmung der Sammlung Zlatými řetězy, Mit goldenen Ketten, aus dem Jahre 1926 in Biebls Dílo, Werk, 1951, auf.) Auch über die Rückreise wissen wir nichts Genaues; sicher ist nur, dass der Dichter im Februar 1927 wieder zu Hause war. - Die 
Bezručs Ostrava oder Jakub Demls Tasov ist auch das ferne Java durch das Verdienst von Biebls Gedichten Teil einer imaginären tschechischen Topographie geworden; so mancher tschechische literarische Indonesien-Besucher sah Java bereits mit Biebls Augen. Auf Biebls Verse bezieht sich etwa Jiří Marek in der an Karel Čapek anklingenden Reisebeschreibung Země pod rovnikem (1956, dt. Land unter dem Äquator, 1958) oder Norbert Frýd im Band S pimprlaty do Kalkaty (1960, Mit den Marionetten nach Kalkutta). Ein Kapitel „Auf den Spuren von Konstantin Biebl“ finden wir in Miroslav Oplts Buch Hledáni Indonésie (1989, Suche nach Indonesien), und Pavel Zvolánek erinnert in Neznámá Indonésie (2004, Das unbekannte Indonesien) an Biebls Gedicht Javanky (Die Javanerinnen). Auch Josef Kebza, der in den sechziger Jahren als Fluginstruktor in Indonesien gewirkt hatte, knüpfte als Dichter an Biebl an, und zwar in der Sammlung A co by řekla Kendedés (1975, Und was würde Kendedés dazu sagen).

Diese Rezeption beginnt schon in den zwanziger Jahren des vorigen Jahrhunderts. Im Herbst 1926, noch bevor Biebl aus Asien nach Prag zurückgekehrt war, erschien Seiferts Gedicht Tři hořká jadérka (Drei bittere Kerne) im Buch Slavík zpivá špatně (Die Nachtigall singt falsch), das von Biebls Reise und einem seiner Briefe inspiriert war. Seifert evoziert hier, ähnlich wie Biebl, Exotik und Heimat als Gegenpole. Unmittelbar nach Biebls Rückkehr und der Herausgabe seines Gedichtbandes S lodí jež dováži čaj a kávu (1927, dt. Mit dem Transporter für Kaffee und Tee) schrieb František Kovárna, dass Biebls Java-Bilder so suggestiv sind, dass er dieses Land gar nicht mehr aus eigener Erfahrung kennenlernen möchte:

Věřte mi, že se nechci do smrti na Jávu podívat. Kost'a mi o ní vypravoval, představil jsem si zbořená města, pralesy, javánské ženy, vykourril trávou vonící cigaretu, jež měla být omamná, čichal $\mathrm{k}$ muškátovému ořechu, který je ostatně možno koupit v každém koloniálním obchodě, něco jsem viděl na fotografiích [...], pak jsem slyšel Kost’ův sametový hlas, když mi o všem vykládal, a nyní už opravdu nechci Jávu ani vidět, a kdybych tam někdy přijel, dám si oči zavázat šátkem, abych neviděl nic a neztratil svou sladkou představu Jávy (Kovárna 1928: 226).

Glaubt mir, ich will Java bis zum Tod nicht sehen. Kost'a hat mir davon erzählt, ich habe mir zerstörte Städte, Urwälder, javanesische Frauen vorgestellt, habe eine nach Gras duftende Zigarette geraucht, die berauschend gewesen sein soll, ich habe an einer Muskatnuss geschnuppert, die man übrigens in jedem Kolonialwarengeschäft kaufen kann, einiges habe ich auf Photographien gesehen ..., dann habe ich Kost'as samtene Stimme gehört, wenn er mir von all dem erzählte, und nun möchte ich Java wirklich nicht mehr sehen, und wenn ich irgendwann dort hin kommen sollte, lasse ich mir die Augen mit einem Tuch verbinden, damit ich nichts sehe und meine süße Vorstellung von Java nicht verliere.

Orientalische Motive ziehen sich durch Biebls gesamtes Werk. In seiner ersten eigenständigen Sammlung Věrný hlas (1924, Die treue Stimme) finden wir das Gedicht Japonský dřevoryt (Japanischer Holzschnitt). Die folgende Sammlung, Zlom

Übersetzungen aus dem Tschechischen stammen, wenn nicht anders angegeben, von Gertraude Zand. 
(Der Bruch), erschien zu Beginn des Jahres 1925; die Ausgabe wurde aber im Oktober 1928 so grundlegend überarbeitet, dass eigentlich ein neuer Band entstanden ist. Orientalische Motive (Ägypten, der Nil, Sarkophage, der Pharao) bringt hier das Gedicht Pyramidy bdí (Die Pyramiden wachen; in der ersten Ausgabe werden die Pyramiden - eine bizarre Sicht - den mährischen Ostereiern gegenüber gestellt) und das Gedicht Odjezd (Abfahrt; nur in der zweiten Ausgabe), das die exotische Reise des Dichters ankündigt:

Slyš na řetězech / stoupají z hlubin těžké kotvy / vzduch zlehka se třese / Vzhůru do Indie / Sbohem Čechy / já jedu na Cejlon / z továrních komínů zpívající sirény / rozplétají leknínové věnce (Biebl 1928b: 25).

Horch auf Ketten / steigen aus den Tiefen schwere Anker auf / die Luft bebt leicht / Hinauf nach Indien / Adieu Böhmen / ich fahre nach Ceylon / aus den Fabriksschloten singende Sirenen / entflechten Seerosenkränze.

Biebls drittes Buch Zloděj z Bagdadu (1925, Der Dieb aus Bagdad) evoziert schon allein durch seinen Titel den Orient. Im Eingangsgedicht treffen wir auf die Vorstellung von einer ,tropischen Weihnacht“, die allerdings mit dem Jesukind verbunden ist, mit Bauernhäusern auf dem Dorf und mit der Mitternachtsmette am Heiligen Abend, also mit sentimental mitteleuropäischen Weihnachtsrequisiten. In anderen Gedichten tauchen orientalische Realien auf (Bakschisch, Haschisch, Mohammed, Moschee), aber wieder in überraschender Verbindung mit einem tschechischen Couplet (im Gedicht Zloděj z Bagdadu) oder mit dem lyrischen Subjekt (Poklad, Der Schatz) in einer Situation, die wir als quasiautobiographisch bezeichnen können. Durch und durch exotisch beginnt in derselben Sammlung das Gedicht Prales (Der Urwald): „V korunách stromů spí opice a barevní ptáci / pod modrými nebesy -“ (In den Kronen der Bäume schlafen Affen und bunte Vögel / unter dem blauen Himmel -) Aber es kommt, was für einige von Biebls Texten charakteristisch ist, gewissermaßen zu einer Entgleisung aus der evozierten gegenständlichen Welt, wenn die zweite und dritte Strophe die eingeführte fiktive Situation negieren: „Na zamrzlém okně se kácí / květ, / list, / strom, stromy, pralesy - // V mém dechu palmy zmizely, / stádo sloní v něm se ztrácí [...]“ (Biebl 1925: 22; Auf dem zugefrorenen Fenster stürzt / eine Blüte, / ein Blatt, / ein Baum, Bäume, Urwälder - // In meinem Atem sind die Palmen verschwunden, / eine Herde Elefanten verliert sich in ihm [...]). Die Realität verwandelt sich (selbstverständlich im Rahmen der präsentierten fiktiven Welt) in eine Vorstellung, in eine Imagination. Es ist ein Verfahren, das sich weiter vertieft bis zu dem, was wir mit Pavol Winczer (2000: 67) als Infragestellung des ontologischen Status des Gedichts bezeichnen können - siehe die Texte in Biebls nächstem Band, Zlatými řetězy (1926, Mit goldenen Ketten). Gerade in dieser Sammlung schwimmt der Dichter bereits voll auf den Wassern der exotischen Launen des Poetismus. Bezeichnend ist das Eingangsgedicht:

Zlatými řetězy k lampě přikován / můj stín, jak černoch v smutku, / dnes básník svoje srdce dá třeba za banán, / za žlutý banán. [...] Loupejte, prsty, žhavou kưru. Loupejte pomeranč. / Oranžovou kolébku slunce / kolébával oceán. // Básník, / pak pilot - / Sám bủh ví co na ko- 
nec. // Snad sežehnut nebem, snad blesky tetován / v přístavní krčmě umírá Malajec. // Na prsou válečná lod'. / Na rukou snědá žena (Biebl 1926: 11).

Mein schatten ist wie in trauer der mohr / an die lampe geschmiedet mit goldenen ketten, / der poet für eine banane sein herz heut verlor, / eine banane gelb. [...] Finger schält ab, die glühende schale. Schält ab die pomeranze. / Orangene wiege der sonnenbrände / der ozean hob sie empor. // Poet, / dann pilot - / gott allein weiß, wie die reihe. // Wohl vom himmel versengt, tätowiert vom blitzphosphor / in der hafenkneipe stirbt ein Malaye. // Auf seiner brust das kanonenboot. / Auf dem arm die schwarzbraune frau. (Übers. E. Schreiber, in Kundera - Schreiber 2004: 148)

Hier werden exotische Bilder und die ihnen auf den ersten Blick entfernte Welt des lyrischen Subjekts durch freie Assoziationen miteinander verbunden (Schatten Schwarzer - Banane - Orange - Ozean - tropische Sonne - Hafenkneipe - Malaye), so dass sie sich in alogischen, nur auf der Imagination beruhenden Zusammenhängen mischen können. Genauso ist es im Gedicht $\mathrm{Na}$ cestu (Auf die Reise), wo sich Bilder vom Prager Petř́n mit Bildern vom Stillen Ozean abwechseln; der Vorstellungszusammenhang zwischen „kapitán“ (Kapitän) und „mohykán“ (Mohikaner) basiert vielleicht nur auf dem Reim. Die fiktive Welt des Gedichts materialisiert sich in der Wortfindung: Schachfiguren gehen auf ein Begräbnis, Dragoner aus Lebkuchen fahren zu Manövern. Gerade die „Reisegedichte“ der Sammlung Zlatými řetězy (Monte Carlo, Na Riviéře, An der Riviera, Č́na, China) beruhen oft auf einem Bild oder einer Handlung, die nur aus einer sprachlichen Geste herauswachsen.

Das Inventar von Biebls exotischen Motiven unterscheidet sich dabei nicht allzusehr von dem seiner Altersgenossen. Die Exotik der poésie du départ begeisterte alle avantgardistischen Dichter. Nach dem Vorbild von Baudelaires L'invitation au voyage oder Rimbauds Le Bateau ivre stellte sie den abenteuerlichen oder subversiven Gegenpol zum wirklichen oder vermeintlichen Grau des Alltags dar, transponierte die Sehnsucht nach einer besseren Welt und das verlorene Paradies. Das Reisen - sei es auf realen Erlebnissen begründet oder nur auf der Vorstellung - brachte einen raschen Wechsel von Orten und neuen Eindrücken. In den dreißiger Jahren sagte Biebl in einem Rundfunkvortrag:

Ve smyslu Baudelairově jsme všichni cestovateli. [...] Od školních let jsem lovcem emocí. Miluji skutečnost, ale také snění, a proto se rád pohybuji na rozhraní obou světů, kde skutečnost se přelévá $\mathrm{v}$ sen a naopak, kde krása rodí se z krásného pohledu a doznívá potom dlouho při zavřených očích. Jsem cestovatelem všech dob a nejrůznějších snů. (Biebl 2001: 79-80)

Im Sinne Baudelaires sind wir alle Reisende [...] Seit meinen Schuljahren jage ich Emotionen nach. Ich liebe die Wirklichkeit, aber auch das Träumen, und darum bewege ich mich gerne an der Grenze zwischen beiden Welten, wo die Wirklichkeit in den Traum hinüberläuft und umgekehrt, wo die Schönheit aus einem schönen Anblick geboren wird und dann lange bei geschlossenen Augen nachklingt. Ich bin ein Reisender aller Zeiten und der mannigfaltigsten Träume.

Der Rousseausche Kult des noble sauvage kreuzte sich in den Gedichten über die Tropen und Ozeane mit der Vorliebe für die Kulturen der Naturvölker, die überraschenderweise mit einigen Zügen der Avantgarde-Ästhetik im Einklang standen. Seifert und nach ihm Biebl und Nezval (Sbohem a šáteček, 1934, Adieu und Tüchlein) konstitutierten die Gestalt der tschechischen Avantgarde-Reisebeschreibung 
(Macura 1987). Für die tschechischen poetistischen Dichter ist eine sorglose Leichtigkeit charakteristisch:

Putuje tulák s cigárem po světě

a všude veselo mu je

Včera kráčel po horách v Tibetě

dnes zpívá a na moři pluje [...]

(Biebl 1928a: 37)

Die Welt durchwandert der Vagabund

Und nirgendwo wird es ihm weh

Heut streunt er durch Tibet Zigarre im Mund

Morgen singt er und fährt über See [...]

(Übers. F. Fühmann, in Kundera - Schreiber 2004: 177)

Die lyrische Reisebeschreibung zeichnet sich durch ein größeres Maß an Selbstreflexion und Fiktion aus als neutrale Resieliteratur, die auf sachlichen Informationen basiert. Zum Objekt der Poesie wird das Dichten selbst als Lebensprinzip und spielerische Erotik:

S lodí jež dováží čaj a kávu

pojedu jednou na dalekou Jávu

Za měsíc lod' když vypluje z Janova

stane u zeleného ostrova

Pojedem spolu já a ty

vezmeš s sebou jen kufrík a svoje rty [...]

(Biebl 1928a: 34)

Mit dem Transporter für Kaffee und Tee

stechen wir morgen nach Java in See

Fahren vier Wochen durchs Meerglitzern dann

legen an einer grünen Insel wir an

Lassen zu zwein von der Brise uns fächeln

Nimm nur dein Köfferchen mit und dein Lächeln [...]

(Übers. F. Fühmann, in Kundera 1993: 240)

Die Asienreise verwirklichte Biebl am Höhepunkt seiner Schaffenskraft und er kehrte in seinem Werk immer wieder zu ihr zurück. Die erwähnten Gedichtbände, Zlatými řetězy, S lodí jež dováži čaj a kávu, die zweite Ausgabe des Zlom und der folgende Nový Ikaros (1929, dt. Der neue Ikaros) sind zweifellos der Höhepunkt seines Werkes. Bilder und Motive aus Java tauchen auch in den Reiseaufzeichnungen in Prosa auf, die in Zeitschriften erschienen sind (Domov a svět, Heimat und Welt, und Lidové noviny, Volkszeitung), der Vorgesang zum unvollendeten Gedicht Slametan war von ihnen inspiriert (Slametan sind rituelle Zeremonien auf Java, denen Clifford Geertz später die umfangreiche Publikation The Religion of Java, 1960, widmete), der dritte Gesang des Nový Ikaros, das dreiteilige Gedicht Džungle (Der Dschungel) in der Sammlung Nebe peklo ráj (1930, Himmel Hölle Paradies), die gesondert herausgegebene Prosa Plancius (1931; dt. Plantius 2000), die phantastische Prosa Na hostině mrtvých (im Sammelband Surrealismus, 1936; dt. Bei einem To- 
tenmahl, 2003), die Abteilung „Na trůně rýžových poli““ (Auf dem Thron der Reisfelder) in der letzten Sammlung Bez obav (1951, Ohne Sorgen).

Offensichtlich spielt hier auch die innere Disposition eine Rolle. Augenzeugen zufolge wirkte Biebl in seinem Auftreten oftmals so, dass er mit seinen Bewegungen und mit der geschmeidigen Art seiner Gestik den Indonesiern glich (Konrád 1963: 19). Auf einigen Photographien sieht dieser „dunkle Bursch“ (Eigencharakteristik im Gedicht Jaro, Frühling) in Věrný hlas (Die treue Stimme) mit gebräuntem Teint und mandelförmigen Augen fast wie ein Mischling zwischen einem Europäer und einem Malayen aus. Sein Reisefeuilleton Indové (Die Inder) aus dem unvollendeten Buch Cesta na Jávu (Reise nach Java, Lidové noviny 1927) und die Prosa Plancius, ein stilisiertes Bild von der Reise des Autors auf dem Meer, schildern zwei Situationen, in denen der Erzähler wirklich für einen Mischling gehalten wird.

Diese Szenen sind sehr kritisch Rassismus und Kolonialismus gegenüber. Biebls Gedichte und Prosatexte aus Ceylon und Java missachten die stereotypen Bilder von „sich“ und dem „,anderen“, die auf der Privilegiertheit der eigenen Rasse und Kultur beruhen. Der Autor ersetzt sie durch feinsinnig wahrgenommene Bilder kultureller Alterität, welche er mit eigener Stimme sprechen lässt (z. B. in den Gedichten Amín bzw. Toké). Die vermeintlich kulturell höherstehende „Zivilisation“ kann sich so als Barbarei erweisen. Daher können wir Biebls Texte als Vorläufer späterer Richtungen des Orientalismus und Postkolonialismus erachten, die den Eurozentrismus in Bezug auf den Orient problematisieren (z. B. Spivak 2006).

Davon zeugt z. B. ein Ausschnitt aus dem Prosatext První noc na Jávě (Die erste Nacht auf Java), der im Nachlass erhalten ist. Die Verzauberung durch die exotische Andersheit, die kulturelle Alterität und die für Biebl charakteristische Eingenommenheit für Bilder vom Tod, vom Übergang zwischen Leben und Tod, von der Belebung von Dingen und der Auferstehung von den Toten verwandeln sich hier in die Vision eines Dschungels als einer eigenen, für die Europäer undurchdringlichen Welt. Diese Welt ist auf eine geheimnisvolle Ordnung des natürlichen Seins gebaut und der westlichen Zivilisation unzugänglich, sofern diese nur auf der rationalen Einsicht gründet, auf einer für die Vernunft überschaubaren, berechenbaren und daher auch manipulierbaren Vorstellung von der Realität. Und sofern sie den kulturellen Unterschied nicht als etwas Untergeordnetes, sondern als etwas Eigenständiges wahrnimmt.

Indický dům je domovem mrtvých, zastávkou k nirvánám, předpeklím netopýrů, očistcem ropuch a jiných duší, které se tu pohybují bez bázně, zcela nenuceně, podomácku, bez ohledů na Holand'any, bez ohledu na vás, nebot' jsme tu všichni jenom jaksi dobrovolně a dočasně trpěnými nájemníky záhrobí.

Nesmíte se tu př́lišs roztahovat se svým západním rozumem, a když, musíte si aspoň uvědomit, že nejste-li hosty mrtvých, jste zajisté hosty džungle, která vás dostatečně přesvědčila o tom, že posud neztratila svou moc nad Batávií a všemi ostatními městy a kampongy po celé Jávě, džungle, věčná a pravdě tajemná, která nezmizí tam, kde se postř́lejí negři a vykácejí pralesy. Ne, stane se jenom ještě tajemnější, ještě o něco záhadnější. Tam, kde kdysi šuměly stromy dammarové, vládne ted' mlčení milionů. (Biebl 2001: 61-62) 
Ein indisches Haus ist ein Zuhause für die Toten, eine Haltestelle zum Nirwana, eine Vorhölle der Fledermäuse, ein Fegefeuer der Kröten und anderer Seelen, die sich hier ohne Angst, ganz ungezwungen, wie zu Hause bewegen, ohne Rücksichten auf die Holländer, ohne Rücksicht auf euch, denn wir sind hier alle nur irgendwie freiwillig und vorübergehend geduldete Mieter des Jenseits.

Ihr dürft euch hier nicht allzusehr mit eurer westlichen Vernunft ausbreiten, und wenn, müsst ihr euch wenigstens bewusst machen, dass, wenn ihr nicht Gäste von Toten seid, so sicher Gäste des Dschungels, der euch ausreichend davon überzeugt, dass er bislang seine Macht über die Batavia nicht verloren hat und über alle übrigen Städte und Kampongs auf ganz Java, des ewigen und des wahrlich geheimnisvollen Dschungels, der dort nicht verschwindet, wo die Neger alles zusammenschießen und die Urwälder abholzen. Nein, er wird nur noch geheimnisvoller, noch ein wenig rätselhafter. Dort, wo einst die Dammarbäume rauschten, herrscht jetzt das Schweigen von Millionen.

Biebl stieß hier auf ein großes Thema der Literatur des 20. Jahrhunderts, wie wir es etwa aus dem Werk von Joseph Conrad oder William Faulkner kennen. Jener Dschungel, das natürliche und ursprünglichere Sein, ist nicht nur etwas Äußerliches, es ist auch der Dschungel in uns. Biebls „mlčení milionü“ (Schweigen von Millionen) erinnert an „strašné mlčení čtyř set milionů“ (das schreckliche Schweigen von vierhundert Millionen) farbiger Bevölkerung im britischen Imperium, welches Karel Čapek in seinen Anglické listy (Englische Blätter) erwähnt (1980: 91-92) und welches er in seinem berühmten Roman durch das schreckliche Schweigen der Molche vergegenwärtigt. Der racial turn, der in den letzten Jahrzehnten in den Kulturwissenschaften eingesetzt hat, nimmt oft gerade Literatur als einen Ort wahr, an dem sich rassische Stereotypen festsetzen und auf den ihr Wandel projiziert wird. Tzvetan Todorov zeigte in La conquête de l'Amérique, dass die Kolonialisierung nicht nur auf der Eroberung des Landes beruht, auf der Ausbeutung des Reichtums und der Versklavung der Bevölkerung, sondern auch in der Kontrolle der Kommunikationsmittel. Die Befreiung bedeutet dann nicht nur den Kampf gegen die koloniale Autorität, sondern auch die Suche nach der eigenen Identität und nach der eigenen Sprache. Konstantin Biebl stellt dem Verstummen den Dialog mit der anderen Kultur und Religiosität gegenüber, deren Stimme er als gleichwertig respektiert. Diese Stimme durchdringt bei ihm beständig die Stimme der eigenen Kultur.

In Biebls Gedichten ist die Durchdringung der realen Sachlichkeit mit dem Geheimnisvollen und der Imagination offensichtlich. Einzelne malayische Wörter oder Namen, die auftauchen, sind in den Aufzeichnungen des Autors belegt, gleichzeitig jedoch wirken sie mit einer geheimnisvollen Zauberhaftigkeit. Der Autor erklärt sie nämlich im Unterschied zum üblichen Usus reisebeschreibender Werke nicht, sondern überträgt sie direkt in den abweichenden tschechischen Kontext: „Opice skáčou přes kapok a rambutan, / mám ve větvích opice rád, / když skáčou a skáčou přes kapok a rambutan“ (Toké; Die Affen hüpfen über den Kapok und den Rambutan / ich habe die Affen in den Ästen gern / wenn sie hüpfen und sie hüpfen über den Kapok und den Rambutan) - der Kapok ist ein tropischer Baum, der Rambutan ebenfalls und auch seine Frucht heißt Rambutan, ,... otřásla mnou Bromo / Stejně jako Merapi / Klut a Sindoro“ (Vorgesang zum Gedicht Slametan; es erschütterte mich Bromo / 
Genauso wie Merapi / Klut und Sindoro) - Bromo, Merapi, Klut und Sindoro sind Vulkane auf Java.

Auf ähnliche Weise vermischt sich Sachlichkeit mit dem Geheimen und Grotesken, wenn die Exotik direkt das europäische und tschechische Leben und seine realen Details durchdringt, respektive mit ihnen Platz tauscht. Das machen auch die vom Autor nach und nach vorgenommenen Bearbeitungen der Texte deutlich, etwa im Gedicht Toké: die javanesische Eidechse „blázní, má Viktorčin hlas“ (1928a: 59; sie ist verrückt, sie hat Viktorkas Stimme). In der ursprünglichen Handschrift stand noch: „Ještěrka křičí, má šílený hlas“ (Die Eidechse schreit, sie hat eine wahnsinnige Stimme). Gerade die Verbindung der javanesischen Eidechse mit Viktorka (einer Figur aus Božena Němcovás Babička, Großmutter) gibt dem Text eine neue semantische Konnotation, die auch für weitere Gedichte in der dritten Abteilung der Sammlung charakteristisch ist. Ebenso verbindet sich die Exotik mit den europäischen Kulissen, wenn in der Wildnis der Gesang von einem Rabbi und von mährischen Lehrern ertönt (53). Gegenüber dem Wortlaut in der Handschrift („Někdo zpívá pohřební žalmy“, Jemand singt Begräbnispsalmen) gewinnt das Gedicht durch die Vorstellung des Rabbi und des mährischen Lehrerchors im Urwald an bizarrer Magie. Der Vers „a věčně věčně zpívají brouci“ (61, und ewig ewig singen die Käfer) scheint auf den berühmten Roman Og bakom synger skogene (Und ewig singen die Wälder) des norwegischen Schriftstellers Trygve Gulbranssen anzuspielen. Dieser erschien allerdings erst einige Jahre später, im Original 1933 und tschechisch 1936 (deutsch 1935), sodass wir die scherzhafte Anspielung erst im Nachhinein wahrnehmen können. Im Gedicht Nový Ikaros liest man: ,ale ze všeho nejvíce dojala mne krabička zápalek / kterou jsem našel hluboko v džungli“ (Biebl 1929a: 46; aber am meisten von allem beeindruckte mich eine Schachtel Streichhölzer / die ich tief im Dschungel fand). Dieses Motiv fehlt wiederum in der ursprünglichen, in einer Zeitschrift gedruckten Version. Es handelt sich offensichtlich um eine Anspielung auf Paul Gauguin, denn eine kleine Zündholzschachtel kann man auf seinem Bild Femmes de Tahiti. Sur la plage finden; übrigens wird auch Gaugin selbst im Gedicht erwähnt. Das berühmteste von den javanesischen Gedichten ist Protinožci (Die Gegenfüßler); in der Handschrift des ersten Teils heißt es: „Na druhé straně světa zas jdou lidé s nohama vzhůru / Musím stále mysliti na jejich rozbité podrážky“ (Auf der anderen Seite der Welt gehen die Menschen mit den Füßen nach oben / ich muss immer an ihre kaputten Sohlen denken). In der Buchausgabe ist die Vorstellung von der Heimat als einer Welt der „Gegenfüßler“ ins Groteske getrieben, das erotische Motiv nimmt überhand.

[...] Na domov myslím a proto se dívám do země kdyby zem byla průhledná všem ženám v Evropě bylo by viděti pod sukně 
Sem tam se míhají nohy v bílém prádle

jako když baletky

v Paříži tančí po zrcadle

Musím stále mysliti na jejich ramena

oči ústa vlasy

a ňadra ňadra zejména $[\ldots]$

(Biebl 1928a: 61-62)

[...] Ich denke an die Heimat drum schaue ich gegen die Erde

wenn die gute Kugel jetzt durchsichtig wäre

könnte ich allen Frauen Europas unter den Rock sehn

Die Füßchen flattern flink in der weißen Wäsche

wie wenn Ballettmädchen in Paris

auf geschliffenen Spiegeln tanzen

Ich muß immer an ihre Arme denken

an ihre Augen Lippen Haare

und Brüste vor allem an ihre Brüste [...]

(Übers. F. Fühmann, in Kundera 1993: 241)

2. Biebls Texte, die - wie angfangs erwähnt - im tschechischen Kontext als intertextuelle Anregungen wirkten, knüpfen selbst wieder an Prätexte an. Das betrifft vor allem das Wirken von Guillaume Apollinaire. Das Poem Nový Ikaros (1929) ist eines der letzten Gedichte und offensichtlich auch ein Höhepunkt in der wohlbekannten Reihe von tschechischen Werken, die sich an Apollinaires Zone und verständlicherweise auch an ihrer tschechischen Übersetzung durch Karel Čapek inspirierten. Wie Pavol Winczer anführt, jährte sich Apollinaires Todestag im Herbst 1928 zum zehnten Mal (Winczer 2000: 62), und Karel Teige redigierte aus diesem Anlass die dritte Nummer der Avantgardezeitschrift ReD als „Souvenir de Guillaume Apollinaire“. Weil Biebl in dieser Zeit zu den prominenten Vertretern der Avantgarde gehörte und regelmäßig in ReD publizierte, kann man annehmen, dass er diese Kampagne - in deren Verlauf Apollinaire zu Johannes dem Täufer der modernen tschechischen Poesie ausgerufen wurde - verfolgte und dass sie bei der Entstehung seines Gedichts eine Rolle gespielt haben könnte.

Die Gestalt des Ikaros taucht übrigens auch in Apollinaires Zone auf - neben Simon dem Magier, dem Propheten Elias und weiteren Gestalten, die eine Parallele und eine Vorahnung von Jesus Christus abgeben; er wird hier kurioserweise als Wunder-Aviatiker dargestellt. Ähnlich schwebt auch Biebls Ikaros im freien Flug hoch über der Erde. Der „Neue Ikaros“ wird im zweiten Gesang eindeutig mit der Figur des Dichters identifiziert: „Básník nový Ikaros lehce se vznáší v prostoru i čase" (Biebl 1929a: 34; Der Dichter, ein neuer Ikaros, schwebt leicht im Raum wie in der Zeit).

Eine Grenzen überschreitende Leichtigkeit gilt auch für die Konstruktion des Gedichts. Biebl stellt mit noch größerer Freiheit als Apollinaire das Reale und das Surreale, das Autobiographische und das Fiktive, das Tragische und das Groteske nebeneinander. Die Diskontinuität verstärken zahlreiche Motive der Vergänglichkeit 
und der Sinnlosigkeit des menschlichen Lebens - sie erreichen den Gipfel am Ende des ersten Gesangs in den Bildern von einem wahnsinnigen Militärtrommler, der ins Finstere und ins Leere trommelt, weil niemand anderer mehr am Leben ist. Hier spiegelt sich wie in einer Reihe von anderen den Krieg thematisierenden Gedichten die persönliche Erfahrung des Autors wider. Konstantin Biebl hatte als einziger seiner Dichtergeneration 1916-1918 an den Kämpfen des Ersten Weltkrieges teilgenommen, und aus seiner Korrespondenz geht hervor, dass diese Bilder des Nový Ikaros ihren Ursprung in einem Traum von der Schlacht um Verdun haben.

Pavol Winczer (2000: 63 f.) hat darauf hingewiesen, dass sich genauso wie beim späten Apollinaire (Calligrammes) auch bei Biebl Motive des Krieges mit der erotischen Liebe verbinden. Neben dem von Winczer erwähnten Text Chef de section kann man auch das Gedicht Merveille de la guerre anführen:

Que c'est beau ces fusées qui illuminent la nuit

Elles montent sur leur propre cime et se penchent pour regarder

Ce sont des dames qui dansent avec leurs regards pour yeux bras et coeurs

$[\ldots]$

C'est aussi l'apothéose quotidienne de toutes mes Bérénices dont les chevelures sont devenues des comètes

(Apollinaire 1970: 137)

Gerade in diesem Gedicht betont das lyrische Subjekt seine Allgegenwart in Anknüpfung an den Ikaros-Mythos (,,je commence à être partout / C'est moi qui commence cette chose des siècles à venir / Ce sera plus long à réaliser que non la fable d'Icare volant“, Apollinaire 1970: 138), was eine direkte Inspiration für Biebls Poem gewesen sein könnte. Umso mehr, als auch hier das kannibalische Motiv vorkommt: „La terre a faim et voici son festin de Balthasar cannibale“ (138). Allerdings ist die Art und Weise, wie Biebl mit diesem Motiv umgeht, deutlich anders:

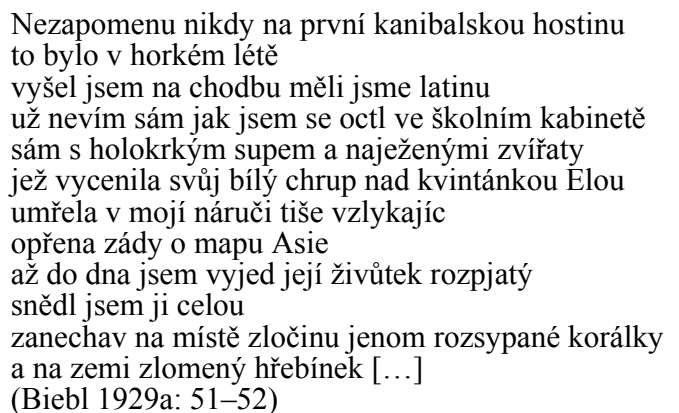

Ich werde nie das erste kannibalenmahl vergessen / das war ein einem heißen sommer / wir hatten grad latein und ich ging auf den Gang hinaus / ich weiß selbst nicht wie ich ins naturalienkabinett geriet / allein mit einem kahlschrittigen geier und den gesträubten tieren / die über Ela aus der quinta ihre weißen Zähne fletschten / sie starb in meinen armen leise schluchzend / den rücken angelehnt an eine karte Asiens / bis auf den grund aß ich ihr aufgeknöpftes mieder ab / ich fraß sie ganz / am ort der untat blieben nur verstreut korallen / zerbrochen auf der erde auch ein kleiner kamm [...]

(Übers. E. Schreiber, in Kundera - Schreiber 2004: 242) 
In Biebls Gedicht wird der Schrecken nicht nur ästhetisiert und erotisiert, sondern auch grotesk karnevalisiert. Apollinaires „merveille“, das Wunder, die magische Wunderwirkung der realen und imaginären Wirklichkeit, hat hier auch ihre umgekehrte, ironische Seite.

Jsme jiní lidé válka nás křtila znova

dala ti nové zvučnější jméno

jsi básník Smrti vrhač nádherných min

$[\ldots]$

válka ta umí čarovat

hled’te jak rychle zmizí váš snubní prstýnek

(Biebl 1929a: 19-20)

Andere Menschen sind wir der Krieg hat uns nochmals getauft

gab dir einen neuen klingenden Namen

bist ein Dichter des Todes Schleuderer herrlicher Minen

[...]

Krieg welcher zaubern kann

seht wie hurtig euer Brautring verschwindet

(Übers. O. Pick, Biebl 1929b: I)

Das Motiv der Kultur von Naturvölkern, die eine der Inspirationsquellen für die bildende Moderne war (z. B. Pablo Picasso, Jacques Lipchitz, Emil Nolde, Ernst Ludwig Kirchner, Václav Špála, Josef Čapek), findet sich am Ende der Zone:

Tu marches vers Auteuil tu veux aller chez toi à pied

Dormir parmi tes fétiches d'Océanie et de Guinée

Ils sont des Christ d'une autre forme et d'une autre croyance

(Apollinaire 2007: 22)

Im dritten Gesang des Nový Ikaros dominieren genauso wie in der Sammlung S lodí jež dováži čaj a kávu Bilder von der Natur und Kultur Südostasiens. Die Naturreligion auf Java, ihre Bräuche und Rituale, scheinen ein sagenhaftes goldenes Zeitalter wiederzuspiegeln. Ebenso wie viele andere westliche Reisende sucht Biebl in Asien das Abenteuer, ein ursprünglicheres, erfreulicheres Sein, Vitalität und das erotische Paradies.

Ještě bych našel to místo kde jediným bleskem dlouhého nože

skolil jsem tygra k údivu všech statečných Atčíňanů

do čerstvé krve zabitého zviŕrete hned namáčeli jedovaté šípy

aby nikdy neminuly cíle

a padesát dní a padesát nocí trvala slavnost než snědlo se tři sta na rožni pečených bůvolů nežli se vypilo palmové víno $\mathrm{z}$ pětadvaceti ${ }^{2}$ načatých stromů

nežli mi náčelník nabídl betel

nežli mi odevzdal všechny své zbraně poseté safíry

i safíry posetou dvanáctiletou dceru

jež na břiše dala si vytetovat mé křestní jméno Konstantin

(Biebl 1929a: 44)

${ }^{2}$ In der ursprünglichen Version für die Zeitschrift war sogar von „sto dvaceti“ (hundertzwanzig) die Rede. 
Noch würde ich diesen Ort wiederfinden wo ich mit dem einzigen Blitz eines langen Messers

den Tiger niedergestreckt habe zum Erstaunen aller stattlichen Atchinesen

ins frische Blut des erlegten Tiers tauchten sie gleich die giftigen Pfeile

damit sie niemals das Ziel verfehlen

und fünfzig Tage und fünfzig Nächte dauerte die Feier ehe man die dreihundert auf dem Spieß gebratenen Büffel gegessen hatte

ehe man den Palmenwein von fünfundzwanzig angezapften Bäumen ausgetrunken hatte

ehe mir der Häuptling ein Betel angeboten hatte

ehe er mir alle seine Waffen abgegeben hatte besetzt mit Saphiren

und die mit Saphiren besetzte zwölfjährige Tochter

die sich meinen Taufnamen auf den Bauch tätowieren ließ Konstantin

Ähnlich wie zur selben Zeit Henri Michaux im Amazonas-Urwald (Ecuador, 1929; dt. 1994) findet Biebl in Indonesien nicht nur Exotisches und Interessantes. Er möchte sich der anderen Kultur öffnen, er sucht im Dialog mit ihr neuen Raum in sich selbst. Der Kontakt mit dem Anderen führt auch bei ihm zur Suche nach sich selbst; Reisen bedeutet, sich den Dingen zu öffnen (vgl. Hrbata 2005: 442). Auf Ceylon, Sumatra und Java fand Biebl eine ihm nahestehende Emotionalität, Intuition, Imagination und Geheimnishaftigkeit, die sich vom okzidentalen Weltbild unterschied.

Auch in Nový Ikaros findet sich ein Verfahren, das Biebl schon in den Zlaté retě$z y$ anwandte und das später durch die Gedichte von Ivan Wernisch berühmt wurde. Das lyrische Subjekt zerstört bewusst die (relative) Glaubwürdigkeit der fiktiven dichterischen Welt, indem es die Fiktion als seine bloße Imagination betont.

[...] Vždy znova a znova vrhám se po hlavě do těchto magnetických zon

na kterých se třesou oranžová světýlka

jako z dálky přicházející průvod čínských lampionů

jako zblízka rozevřená tlama zívajících leopardů

vyskakují z nich kopím mávající divoši

zachváceni láskou jako tropickou nemocí

Všichni shořeli na místě jako shoří v kamnech uhlí

jenom jejich srdce zůstalo neporušené v hromádce usínajícího popelu

tam kde dneska nacházejí rubíny [...]

(Biebl 1929a: 54)

[...] Neu immer neu kopfüber werd ich in die magnetischen pupillen stürzen / auf denen zittern irrlichter orange / wie ein von weit her kommender umzug chinesischer lampions / wie das nah aufgerißne maul gähnender leoparden / herausspringend aus ihnen wilde lanzenschwingend / befallen von der liebe gleich einem tropenschüttelfrost / Alle verbrannten auf der stelle wie im ofen kohle / allein ihr herz blieb unversehrt im aschehaufen der erloschen / dort wo man heute die rubine findet $[\ldots]$

(Übers. E. Schreiber, in Kundera - Schreiber 2004: 244)

Apollinaires Christus schwebt frei in den Höhen, Ikaros dagegen - und auch sein Doppelgänger, Biebls lyrisches Subjekt - fällt hinunter (,vrhám se dolů ze skály“, ich stürze mich hinab vom Fels). Vorbild könnte hier eher Baudelaires Gedicht Les Plaintes d'un Icare gewesen sein:

Quant à moi, mes bras sont rompus

Pour avoir étreint des nuées.

[...] 
En vain j'ai voulu de l'espace

Trouver la fin et le milieu;

Sous je ne sais quel oeil de feu

Je sens mon aile qui se casse.

(Baudelaire 2007: 84-85)

Allgemein kann man im Nový Ikaros einen Wechsel zwischen der Bewegung nach oben in die Höhe und dem Fall nach unten feststellen. Das sind übrigens Leitmotive in Biebls Schaffen, und, ruft man sich den selbstmörderischen Sprung aus dem Fenster am 11. November 1951 in Erinnerung, auch in seinem Leben. „Unten“ sind in Nový Ikaros die geheimnisvollen Meerestiefen, deren Abbild in der zweiten Hälfte des zweiten Gesangs in der Vision einer Flut gipfelt, welche auch Prag überflutet. Biebl allerdings karnevalisiert die Tragik wieder auf charakteristische Weise: unter dem Wasser befinden sich das Café Slavia und alle Freunde, aus den Tiefen hört man den Klang von E. F. Burians Band (dem Musiker und Theatermacher Emil František Burian ist der Nový Ikaros gewidmet) und eines Tamtams, eine Krake windet sich in Tanzkrämpfen und muss ins Irrenhaus abgeführt werden.

Ein anderes, wieder naiv groteskes Bild von den Tiefen des Ozeans, des Falls hinunter und des Ertrinkens finden wir im Gedicht $S$ očima knebi (Mit den Augen zum Himmel) in der Sammlung S lodí jež dováži čaj a kávu. Hier wird das Scheitern eines Schiffs geschildert, das nach Asien fährt, der Fall in die Meerestiefen zusammen mit irgendeinem Missionar und die Erwartung der Ankunft im Himmel:

Možná, že stojíme zrovna u nebeských vrat,

nevíme nic, nemáme štěstí.

A potom: jak vůbec chtít zabouchat,

když už nám ztuhly v těle kosti?

Nemohu ani vytáhnout z kapsy zrcátko. Škoda, ty vypadáš!

Ve vlasech samé zelené řasy

a břicho, bratře, tak strašně nafouklé máš.

Vid', tam na světě bývaly lepši časy.

Nesmíme zoufat. Ještě není všemu konec.

My musíme dál, musíme hloub,

tak jako každý pořádný utopenec,

$\mathrm{s}$ očima k nebi, s očima v sloup!

(Biebl 1928a: 44)

Möglich, dass wir gerade vor der Himmelspforte stehen

wir wissen nichts, wir haben kein Glück.

Und dann: wie überhaupt anklopfen wollen,

wenn uns schon die Knochen im Leib erstarrt sind?

Ich kann nicht einmal einen Spiegel aus der Tasche ziehen. Schade, du schaust aus!

In den Haaren lauter grüne Algen

und dein Bauch, Bruder, ist schrecklich aufgebläht.

Gelt, dort auf der Welt waren die Zeiten besser.

Wir dürfen nicht verzweifeln. Noch ist nicht alles zu Ende.

Wir müssen weiter, wir müssen tiefer,

so wie jeder anständige Ertrunkene,

mit den Augen zum Himmel, mit Augen zur Säule erstarrt! 
Das ironische Bild von der „Auferstehung“ ist Teil auch des ersten Gesangs des Nový Ikaros. Dort ist es mit einer Bewegung nach oben verbunden, es sind allerdings Tote aus dem Krieg, die an den Folgen einer Bombenexplosion sterben.

Slyš eroplán padá na hřbitov

a vojenská hudba vrací se zpátky

do tanečního sálu kde mladí důstojníci vyletěli stropem zrovna do oblak

pro tenhle prŕípad už dostali předem svoje železné kříže

[...]

kde nájemníci z pátého patra se stěhují do sklepů

kolem mihnuvší se duše jejich domovníka jež letí do nebe s lopatou

mezi uhlím květákem červenou řípou a zpívajícími brambory

(Biebl 1929a: 21-22)

Horch ein Aeroplan fällt auf den Friedhof

und Militärmusik kehrt zurück

in den Tanzsaal wo junge Offiziere durch den Plafond wieder in die Wolken flogen

für diesen Fall bekamen sie schon im voraus ihre Eisenkreuze

$[\ldots]$

wo Mieter aus dem fünften Stockwerk jäh in Keller übersiedeln

vorüber an der schwindenden Seele ihres Hausmeisters welcher gen Himmel fliegt

samt Schaufel zwischen Kohle Karfiol rote Rübe und singende Kartoffeln

(Übers. O. Pick, Biebl 1929b: I)

Der traditionelle himmlische Gesang der Engel wird durch „zpívající brambory“ (singende Kartoffeln) ersetzt. Wenn Apollinaires Zone auf dem Hintergrund des Pfingst-Mythus und der Himmelfahrt zu verstehen ist (vgl. Stierle 1982), dann knüpft Biebls Nový Ikaros daran nicht nur durch die Suche nach dem Transzendenten an, sondern auch durch seine Profanisierung und groteske Karnevalisierung.

\section{Literatur}

Apollinaire 1970:

Apollinaire 2007:

Baudelaire 2007:

Biebl 1925:

Biebl 1926.

Biebl 1928a:

Biebl 1928b:

Biebl 1929a:

Biebl 1929b:

Biebl 2001:

Čapek 1980:

Hrbata 2005:

Konrád 1963:

Kovárna 1928:

Kundera 1993:
Guillaume Apollinaire, Calligrammes, Paris

Guillaume Apollinaire, Alcools, Brno

Charles Baudelaire, Les Fleurs du Mal, Brno

Konstantin Biebl, Zloděj z Bagdadu, Praha

Konstantin Biebl, Zlatými řetězy, Praha

Konstantin Biebl, S lodí jež dováží čaj a kávu, Praha

Konstantin Biebl, Zlom, Praha

Konstantin Biebl, Nový Ikaros, Praha

Konstantin Biebl, Der Neue Ikaros. Abschnitt, übers. Otto Pick, Prager Presse 10, 13. 1. 1929, Beilage Dichtung und Welt, I

Konstantin Biebl, Cesta na Jávu, ed. J. Sedláček, Praha

Karel Čapek, Cestopisy I, ed. Jarmila Víšková, Praha

Zdeněk Hrbata, Prostory, místa a jejich konfigurace v literárním díle, in: Daniela Hodrová u. a. (eds.), Na cestě ke smyslu. Poetika literárního díla 20. století, Praha, 315-510

Karel Konrád, Nevzpomínky, Praha

František Kovárna, Vzácné jubileum, Literární rozhledy 12, Nr. 6, 225-226

Ludvík Kundera (ed.), Die Sonnenuhr. Tschechische Poesie aus 11 Jahrhunderten, 2. Aufl., Leipzig 
Kundera - Schreiber 2004: Ludvík Kundera, Eduard Schreiber (eds.), Adieu Musen. Antholo-

Macura 1987: $\quad$ Vladimír Macura, Básnický cestopis, in: Poetika české meziválečné ligie des Poetismus, München

Sixta 1962: teratury, Praha, 33-55

Stierle 1982: $\quad$ Karlheinz Stierle, Babel und Pfingsten. Zur immanenten Poetik von Jiří Sixta, Ideový a umělecký vývoj Konstantina Biebla, in: Tři studie o moderní české literatuře, Praha, 41-81 Apollinaires ,Alcools“, in: Rainer Warning - Winfried Wehle (eds.),

Spivak 2006: Lyrik und Malerei der Avantgarde, München, 61-112

Winczer 2000: Gayatri Chakravorty Spivak, In Other Worlds, New York Pavol Winczer, Súvislosti v čase a priestore. Básnická avantgarda, jej prekonávanie a dedičstvo, Bratislava

A bstract: Exoticism and Apollinaire's Traces in Biebl's "S lodi jež dováži čaj a kávu" and "Nový Ikaros". The study deals with the work of the Czech poet Konstantin Biebl that was inspired by his journey to Java island, Indonesia (1926-1927). Primarily, it deals with his collection of poems entitled S lodí jež dováži čaj a kávu (1927), but also with many other texts. The poet is charmed by the exotic spell of the Orient, but he also criticizes the racism and hegemony of the reputedly superior western civilization (predecting the later racial turn in culture in this way). The second part of the study focuses on exploring the influence of the French poet G. Apollinaire on Biebl's poem Novy' Ikaros (1929). Similar to Apollinaire, Biebl also mixes various levels of time and space in his poems, as well as real and surreal scenes, autobiographic experiences, tragic and grotesque levels. However, Apollinaire's „meirveille“, a miracle, has also its opposite and ironic reverse side in Biebl's texts.

K e y w o r d s : Czech poetry, avant-garde, Konstantin Biebl, Java, exoticism, Guillaume Apollinaire

Jiř́i Holý

Renoirova 13/593

15200 Praha 5, Tschechien

holmail@seznam.cz 
